\title{
Foiling Kamesian Belletristic Theory in Mid-Eighteenth-Century Scotland
}

\author{
Abstract: Two disciplinary stories that take place in mid-eighteenth-century Scotland \\ omit an important plotline. One story is that university teaching of rhetoric transformed into \\ belletristic criticism; another is that ideology and culture transformed to reorient rhetorical \\ theorizing toward everyday practices by non-elites. Untold is a story of how familiar \\ protagonists, such as Hugh Blair, clashed with antagonists, such as John Witherspoon, in the \\ Church of Scotland. Telling that story from the antagonists' perspective shows that they reflected \\ on how rhetoric ought to be practiced to manage disagreement in a democratic institution, and \\ used what amounted to Kamesian belletrism as a foil.
}




\section{Introduction}

Two disciplinary stories about rhetorical theory and pedagogy that take place in mideighteenth-century Scotland omit an important plotline. One story is that university teaching of rhetoric transformed from an art of civic debate to belletristic criticism (Howell 441-447; Miller, Formation ch. 6; Potkay). The protagonists in this story are well-known. In 1748 Henry Home, Lord Kames recruited Adam Smith to deliver public lectures on rhetoric in Edinburgh, and Hugh Blair was among the audience members (McKenna 14-15; Ross 91). When Smith went to the University of Glasgow in 1751, Kames helped to recruit first Robert Watson (Bator) and later Blair, "the first official professor of English in Britain" (Ross 94), who modeled parts of his lectures on Smith's (McKenna 15), to continue delivering the lectures. In 1762 King George III designated Blair the first Regius Professor of Rhetoric and Belles Lettres at the University of Edinburgh, and Blair's Lectures on Rhetoric and Belles Lettres (1783) ran to at least seventy complete editions (Ferreira-Buckley and Halloran xvi, xxxiii). That same year Kames' Elements of Criticism was first published and ran to dozens of editions well into the nineteenth century. In fact, Rhodes has credited Scots with inventing university English, and Kames' Elements of Criticism for substituting the term "criticism" for "rhetoric" (26-30). Thus began institutionalized belletrism.

A second story is that in mid-eighteenth-century Scotland, ideology and culture transformed in ways that oriented rhetorical theorizing away from elite social actors in political institutions and toward everyday practices by non-elites. For example, Hauser (22-23) has featured Adam Smith as a key figure in a broad cultural, ideological shift from civic republicanism to civil society, arguing that Smith's free-market theory initiated the economic basis of civil society, and Smith's orienting of judgment about character away from public 
conduct toward private, individual propriety exemplified the moral basis of civil society.

Because the ideological, cultural transformations occurring at this time are so significant, tensions between civic republicanism and civil society have organized analyses of belletristic rhetorics such as Blair's (e.g., Agnew, "Civic"; Longaker, "Political," Rhetorical ch. 3; Walzer, “Blair's).

Kames', Smith's, and Blair's belletrism and significance are well-known, but how did their antagonists in a democratic institution designed for managing conflict and disagreement and presenting arguments before making decisions and voting describe the rhetorical conduct of Blair and his ilk? This is a significant, high-stakes question as processes for managing conflict and disagreement about what is expedient and just give decisions and institutions legitimacy. Answering it adds a plotline to narratives of the formation of university English and composition, exemplifies a recurring clash in competing views of rhetoric (civic debate versus sophistry), and cuts across divisions such as rhetoric as pedagogy, as theory, and as practice. On one hand, some scholars have argued that belletristic rhetorics inculcated civic virtues appropriate for civil society such as moderation, propriety, and the like (e.g., Agnew, "Civic" 2526; Longaker, Rhetorical 8-9; McKenna; Walzer, “Blair's” 269-71, 273, 277, George Campbell 132-36). On the other hand, some scholars have remarked on the elitism and anti-democratic character of belletristic rhetorics (e.g., Broaddus 40; Miller, Formation 246-47, "Witherspoon, Blair" 106). Most recently Harrington has pointed to Blair's criticism of public debating societies as a sign of "the social anxiety linked with the expansion of oratorical practices formerly reserved [...] for an elite group of educated men" ("Developing" 325).

These different conclusions are not incompatible. From a broad, cultural perspective, belletristic rhetorics were designed to equip non-elites for acting in civil society. Polite literary 
criticism was well-suited for a swath of mid-eighteenth-century middling Scots aspiring to act like gentlemen to gain, maintain, and exercise social and economic power, control, and influence: to speak the King's English, to display bourgeois taste, to sustain and rationalize hierarchical order for accruing privilege and moving from a position on the margins of an old, aristocratic society to a new, bourgeois center. But I submit that accounts of the rhetorical conduct of Blair and his ilk by their antagonists showed that Kamesian belletrism was ill-suited for managing conflict and disagreement in a democratic institution designed to reach decisions based on reasoning and argumentation.

The main antagonists in this story were members of the Popular party in the Church of Scotland. They were variously described as "Popular" because they argued for the people of a parish, in addition to patrons, to have a role in settling parish ministers; "Wild" or "enthusiastic" because they were evangelicals; and "high-flying" because they held the church higher than the crown and aristocracy (Donovan 81). Popular party accounts of rhetorical processes in the General Assembly of the Church of Scotland are directly relevant to the question of how rhetoric ought to be designed to manage conflict and disagreement. ${ }^{1}$ The General Assembly is the supreme legislative and judicial body of the Church of Scotland. Like courtrooms or political assemblies in democratic forms of government, it features argument and debate. ${ }^{2}$ As rhetoricians such as Isocrates and Aristotle advocated their views of rhetoric by contrasting them with sophistic views, so members of the Popular party in the Church of Scotland advocated their view of rhetoric by contrasting it with the rhetorical conduct of some Moderate party members. The Moderate best known to scholars of rhetoric was Hugh Blair, who was also a key figure in defending Lord Kames against Popular party calls for censuring Kames for his doctrine of necessity. 
To recover the Popular party's rhetorical theory, I analyze their accounts of their own and Moderate party rhetorical conduct. Analyzing metadiscourse by social actors about their own or others' rhetorical conduct is compatible with contemporary rhetorical theorizing that analyzes the talk of social actors themselves as sources of theory (e.g., Craig; Tracy; Wanzer-Serrano), as well as scholarship on historical theories that analyzes various definitions and conceptions of rhetoric and rationales for the art (e.g., Conley; McKeon). I do not assess the accuracy and fairness of how Popular party members characterize Moderate rhetorical conduct because, regardless, the Popular party account of base rhetoric serves as a foil to their account of ethical, appropriate rhetorical conduct. But in fact the Popular party account of how clergy ought not to practice rhetoric aligns well with Lord Kames' account of how readers ought to practice belletristic criticism. Thus Popular party rhetorical theory brings into sharp relief political implications of Kamesian belletristic theory because it shows how Kamesian belletrism may fare systemically in a democratic institution designed for decision-making by debate.

Following an account of the rise of Moderate party power and institutionalization of Kamesian belletrism, I analyze Popular party rhetorical theory advanced in the early 1750 s as clergy addressed the issue of patronage, an important "Scramble" in the "Human Barnyard" (Burke 442) over sources of authority and power in the Church of Scotland. Doing so illustrates Popular party clergy's account of how rhetoric ought and ought not to be designed to manage disagreement. I conclude that the Popular party advocated a rhetorical theory preferable to Kamesian belletrism.

\section{Kamesian Belletristic Theory and Moderate Party Principles}


Belletristic theory is identified with the Moderate party because the Moderate party was the faction in the Church of Scotland whose members curried favor with patrons to obtain faculty positions in universities, where they then attempted to achieve fame in belles lettres. ${ }^{3}$ The Moderate party began to coalesce in the early 1750 s as members made friends in high administrative places and engaged in behind-the-scenes political maneuvering to gain control of the General Assembly. Blair has been described as "a leading political manager of the Moderate Party, second only to Principal Robertson. Blair may have been even more influential behind the scenes than he was in the pulpit" (Miller, Formation 246; see also Miller, Formation 149-51, "Witherspoon, Blair" 110). Moderate ideology has been described as "Whig-Presbyterian conservatism" (Sher 54); Moderates displayed loyalty to the crown and claimed to be on the side of reason and moderation.

Moderate party power coalesced around support for Lord Kames and against Popular party calls for his censure. Besides recruiting lecturers on rhetoric and belles lettres in Edinburgh and writing Elements of Criticism, Kames was an advocate and later judge on Scotland's supreme civil and criminal courts. He was briefly institutionally tied to the Church of Scotland as a layperson who was named Commissioner to the General Assembly in 1753 and 1754 but not in 1755 (Annals 2: 58). Around that time Popular party members clashed with Moderates over whether to censure Kames for the doctrine of necessity he advanced in his Essays on the Principles of Morality and Natural Religion (1751). As we will see, the Popular party marked out their own rhetorical theory by using what amounted to Kamesian belletristic theory as a foil.

A brief look at the defense of Kames by Moderates and at Kamesian belletristic theory illustrates that how Moderates styled themselves was congruent with Kamesian belletristic theory and points to bases of Moderate power. The issue of whether to censure Kames came to a 
head in the 1755 annual meeting of the General Assembly. Popular party members exhorted clergy "to give warning of the poison contained in these volumes [by Kames and his cousin David Hume], and to testify to the whole Christian world your abhorrence of such principles" (Bonar 2). The issue was passed to the Committee on Overtures, headed by William Robertson, a minister who would become a leader of the Moderate party and aspirant to fame in belles lettres (Sher 103, 139-41). The Committee declined to censure Kames and Hume specifically and instead expressed general abhorrence of "impious and infidel principles which are subversive of all religion" (Annals 2:59). The general censure was a "Moderate success" (Ross 156; see also Sher 65-74).

About one week later an anonymous pamphlet, attributed to Blair and defending Kames and Hume, was published. It illustrates how Moderates styled themselves. Blair put Moderates on the side of moderation: reason against violent zeal, liberty against absolutism, toleration against persecution. Blair styled Moderates in ways congruent with Kamesian belletrism. The similarities point to factors that help to explain how Moderates "dominated the kirk" (Sher 121) beginning in the 1760s and, through political maneuvering, obtained university positions (Sher 135-147) and institutionalized bellestristic rhetoric.

First, both Blair's moderation and Kames' belletrism emphasize the role of reason in maintaining social tranquility. Blair aligned moderation with free inquiry and debate, reason, and social good when he premised, "The freedom of inquiry and debate, tho' it may have published some errors to the world, has undoubtedly been the source from whence many blessings have flowed upon mankind," and "all attempts to infringe so valuable a privilege in cases where the peace of society is not concerned, must ever be regarded with concern by all reasonable men" (“Observations" 226). Likewise, Kamesian belletristic theory featured reasoning in the name of 
social good. He organized Elements around the activity of "judging of taste, and [. . .] reasoning upon it" (1: 6). He touted its social goods from the perspective of those enjoying benefits of peace and commerce resulting from British war and empire-building. According to Kames, "A flourishing commerce begets opulence; and opulence, inflaming our appetite for pleasure, is commonly vented on luxury, and on every sensual gratification: Selfishness [...] extinguishes the amor patrice, and every spark of public spirit" (1: vii). But "in the midst of opulence, what other means to prevent such depravity but early and virtuous discipline" (1: viii) of the kind involved in reasoning upon matters of taste, which "inures the reflecting mind to the most enticing sort of logic" (1:7) and "prepares us finely for acting in the social state with dignity and propriety" (1: 8). Both Blair and Kames call for reasoning in the name of social and political quietude.

Second, Blair aligned the Moderate Party and Kames aligned belletrism with crown support, or the political status quo. Blair alluded to Moderate party support of the crown, especially at the time of the 1745 Jacobite Rebellion when Robertson and other future Moderates volunteered to defend Edinburgh (Sher 38). Blair, Kames, and others of the Moderate ilk curried favor with patrons to obtain positions of power and influence; Blair's eventual appointment as Regius Chair of Rhetoric and Belles Lettres at the University of Edinburgh, and Kames' positions as judge on Scotland's supreme civil and criminal courts were crown appointments. In the pamphlet defending Kames, Blair exclaimed, "At a period when mankind are fully sensible of the blessings they enjoy, and liberty both civil and ecclesiastical is become the dearest possession of the people, and the favourite care of the Prince; what sentiments ought the revival of those insidious and Jesuitical principles ["inquisitorial method of interpretation"] to excite in every sincere friend to our present constitution in Church and State!" ("Observations" 231). 
Likewise, Kames displayed support of the crown by dedicating Elements of Criticism to the king, hoping "for your Majesty's patronage" for a work that "treats of the fine arts, and attempts to form a standard of taste, by unfolding those principles that ought to govern the taste of every individual" (1: vi). Kames described how encouraging the fine arts supported hierarchy and order: "by cherishing love of order, they inforce submission to government: and by inspiring delicacy of feeling, they make regular government a double blessing" (1:v). Supporting the crown was a means of obtaining support of patrons and involved maintaining social and political quietude both to avoid another Jacobite Rebellion and to create conditions for increasing middling economic gains and consolidating power.

Third, Blair presented moderation and Kames presented bellestrism in opposition to violent zeal and persecution. Blair speculated that most members of the Church of Scotland were "animated with a fervent zeal for religion: But, knowing that the perfection of religion is the spirit of moderation, they prize too highly the good of the church to give ear to the counsels of a violent and unchristian zeal, which, by adopting the arts [improper quotation and citation], may justly be thought to pursue the ends of persecution" ("Observations" 231). Likewise, Kames described belletristic criticism as a "strong antidote to the turbulence of passion and violence of pursuit" (1: 8); "a man void of taste [. . . ] has no joy but in gratifying his pride or envy by the discovery of errors and blemishes. In a word, there may be other passions, which, for a season, disturb the peace of society more than those mentioned; but [ . . . these passions, tending assiduously to their gratification, put a man perpetually in opposition to others" (1: 9). However, "the God of nature" has made "the transition [. . . ] sweet and easy, from corporeal pleasures to the more refined pleasures of sense; and not less so, from these to the exalted pleasures of morality and religion" (1:4). 
In short, Blair's stylization of Moderates and Kames' rationales for writing Elements of Criticism featured qualities well-suited for stability and social order in a political system where currying favor with patrons was a path to power. As we will see, Popular party members' accounts of Moderate rhetorical conduct were very different: in their view, Moderates made authoritarian pronouncements instead of arguments, and deployed tyrannical measures to eliminate opposition.

It is one thing to claim to be on the side of reason, social good, order, and moderation, and another to perform that position. I now sketch Kames' account of how belletristic criticism ought to be performed, and show its congruence with authoritarianism.

The core of Kamesian bellestristic criticism was justifying judgments of performances in the fine arts and polite literature. I focus on explaining the form of those justifications and procedural implications of that form or, put differently, its suitability for managing disagreement. For Kames belletristic criticism culminated in a categorical judgment displayed in a single argument based on "principles common to all men" (1: 5). These principles were discovered by "philosophic inquiry" (1: 7): “[B]y studying the sensitive part of human nature, and by learning what objects are naturally agreeable, and what are naturally disagreeable $[\ldots]$ we can pronounce with certainty, that it [a critical judgment] is correct; otherwise, that it is incorrect, and perhaps whimsical" (1: 6). Presumably readers of Elements of Criticism would just need to consult their own feelings to judge whether a performance was "naturally" agreeable or not.

To illustrate, consider examples of a claim about the merit of a performance supported by a rule of criticism which, in turn, is supported by a so-called universal principle of human nature. A mixed metaphor may merit blame (claim), because one should not mix metaphors (rule of criticism), because the mind cannot form an accurate image of a mixed metaphor (principle of 
human nature). Or consider how Kames advocated reasoning upon Shakespeare's line, "You may as well go about to turn the sun to ice by fanning in his face with a peacock's feather" (2: 328; Manolescu, "Motives" 298). According to Kames, the description merits praise (claim), because descriptions should paint in readers' minds "distinct and lively images" (2:326) (rule of criticism), because "one is at a loss, when this is neglected in the description" (2:328) (principle of human nature). Or consider how Kames advocated reasoning about why a room with the dimensions of a long gallery merits blame (claim) (Manolescu, "Traditions" 230): a room should evince proportion rather than the length "far exceed[ing] the breadth" (2: 456) (rule of criticism), because "the mind comparing together parts so intimately connected, immediately perceives a disagreement or disproportion which disgusts" (2: 459-460) (principle of human nature).

These forms of justification by a single argument based on a so-called principle of human nature are authoritarian. In the context of the eighteenth century, they represent what I.A. Richards, reflecting on eighteenth-century rhetorics such as Kames' and Blair's, would later call the "Club Spirit" (78) embodied in the membership of Kames, Blair, Smith, and others in Edinburgh's "Select Society" (Sher 61): only those whose natures had not been corrupted by luxury or manual labor, and who used "the goods of fortune with moderation" (Kames 2: 496) could respond properly. Thus Kamesian belletristic criticism was designed to be a source of social power; only select members of the middling classes had the requisite human nature to act as authorities in matters of taste.

To clarify the authoritarian nature of Kamesian belletristic criticism and to see its broader procedural implications, consider a different mode of belletristic criticism—one compatible with procedures of decision-making involving multiple arguments and debate. Instead of supporting claims of praise or blame with a single, categorical argument based on a so-called principle of 
human nature, belletristic criticism could support claims with multiple arguments based on knowledge of traditions of poetry, drama, literary criticism, and so on. Readers or auditors of those multiple arguments could critically scrutinize the grounds, consult other sources, and so on. In this rhetorical scenario, power is distributed among participants and based on their ability to see the available means of persuasion and make arguments. Those who disagree with a critical judgment would not need to be constrained by gut reactions of a self-selected group naturalized and universalized by using the idiom of the new philosophy of human nature.

In sum, Kamesian belletristic criticism involved making a single categorical argument in a fashionable, philosophical idiom. Principles based on the new philosophy of human nature that served as major premises in the critical argument were based on the experiences and introspection of a self-selected few and given unanswerable authority by being naturalized and universalized. Kamesian belletristic criticism was more conducive to justifying pronouncements than to making multiple arguments based on relevant content knowledge and subjecting them to critical scrutiny.

\section{Popular Party Rhetorical Theory}

John Witherspoon was a leading member of the Popular party. In contrast to the Moderate party, Popular party clergy "remain today the more obscure despite their large numbers and their ability in crises to marshall [sic] majority support over the rival Moderate party in many parishes, presbyteries and synods" (Donovan 81). Witherspoon was Blair's classmate at the University of Edinburgh and the most well-known and outspoken critic of "the Moderate Enlightenment in the Kirk" (Kidd 65). Witherspoon is perhaps best known to students of rhetoric for delivering at Princeton University posthumously published lectures on rhetoric and signing 
the U.S. Declaration of Independence (Broaddus; Halloran; Miller Formation, "John," "Witherspoon, Blair"; Scott). But before he emigrated to colonial America, Witherspoon was active in church politics. He wrote an essay against Kames' doctrine of necessity published in 1753 in the Scots Magazine (Landsman 37), and mocked Kames' book in the pamphlet Ecclesiastical Characteristics (e.g., 55), a satire of the Moderate party considered to be his "most notorious work" (Kidd 66).

Witherspoon's Ecclesiastical Characteristics was part of the clash between the Popular and Moderate parties on the "obnoxious law" (Collins 29) of patronage. The debate over patronage stemmed from the fact that ministers appointed by lay patrons could be seen by local presbyteries and congregations as puppets of the patrons to whom they owed their appointments (Yates 28), and patrons could in fact abuse the system to appoint "lackies and unqualified relations" (Sher 319). Moderates held that decisions of the General Assembly must be executed by presbyteries except in extraordinary circumstances, and that patrons held the power to present ministers. Moderate support of patronage could be explained as an attempt to curry favor with Parliament in hopes that members would consider a request to augment stipends (Collins 31 ), or to prevent religious and political unrest (Sher 53). Members of the Popular party defended the right of presbyters to act according to individual conscience and refuse obedience to decisions of the General Assembly if upon reflection they believed that doing so would be acting sinfully, and held that the approval of parishioners ought to be considered in the settlement of ministers. Moderates' position was compatible with authoritarian modes of managing conflict, and the Popular party's was compatible with decision-making based on multiple arguments and critical scrutiny. 
To explicate the rhetorical theory of Popular party clergy, I analyze key texts for the two cases Witherspoon identified as the impetus for publishing Ecclesiastical Characteristics: for the John Adams case, Adams' speech to the General Assembly; and for the Thomas Gillespie case, “Answers" to Moderates' reasons for dissent and Witherspoon's Ecclesiastical Characteristics (Serious $6 \mathrm{n}$.) ${ }^{4}$ From the Popular party perspective, cracks in the Moderate party façade of moderation become apparent. Popular party clergy advanced a rhetorical theory that called for achieving legitimate decisions through a process of making and critically scrutinizing multiple arguments based on knowledge of relevant subject matter, and used as a foil rhetorical conduct that was authoritarian and coercive and involved blind obedience to orders.

\section{The Case of Adams and his defense speech}

The case of John Adams (Annals 1: 198-212) illustrates the rhetorical theory advocated by the Popular party. Adams held that rhetorical conduct ought to involve making multiple arguments, critically scrutinizing them, and appealing to superior courts, thereby conferring decisions with legitimacy. He used as a foil making a single authoritarian argument and enforcing it with threats of censure. Adams and other presbyters of Linlithgow refused to preside at the settlement of James Watson, presented by the patron Lord Torphichen, despite injunctions of the two previous General Assemblies. The patron protested, and the appeal went to the Synod of Lothian and Tweeddale, who referred the case to the May 1751 General Assembly. At that annual meeting one of the non-obedient presbyters, conjectured to be Adams, made a speech at the Assembly bar reported in the Scots Magazine and reprinted in the Annals of the General Assembly (1: 200-208) that called for moderation. 
Adams began by denying that absolute obedience to authority in all cases is essential to government and to supporting the constitution, and instead argued that "rigid insisting upon strict obedience, in some cases, tended to the hurt of the constitution; while moderation and lenity have been judged the securest measures of strengthening and supporting it" (Annals 1: 200). Adams objected to authoritarianism in both form and procedure when he described "the moderate measures" of advocates in past cases (Annals 1: 201; 1: 202). First, advocates "never confined their aim to the single point of maintaining the authority of the Church"; other circumstances "came under consideration," such as "harmony of the Church, and the peace of the country" (Annals 1: 201). Second, advocates did not "place either the essence or the excellency of our subordination, in the power of Church courts to distress their own brethren. - No; they placed it where it certainly lies, in the access which parties have, when they think themselves injured, to seek redress by appeals to the superior courts" (Annals 1: 201). Here Adams distinguished authoritarian procedure (the power of superiors to exercise institutional power in order to distress subordinates) from preferable rhetorical procedure (the power of subordinates to make arguments as they appeal to superior courts).

Adams advocated using multiple arguments to manage disagreement. He highlighted the "prudence and moderation of former times" (Annals 1: 202) in General Assemblies and especially in a comparable case, when "the difficulties and distress of our case were then set forth in so just and convincing a light, that, so far as we know, there was not a single member of that Assembly who moved to censure, or so much as to testify any disapprobation of our conduct, in not executing the order of the preceding Assembly 1749" (Annals 1: 202). According to Adams, the process of setting forth a case contrasted with the Assembly's current conduct: despite the representation of the presbyters' difficulties in settling Watson, "the order was 
renewed in a more peremptory manner than before, and that is the order which we are now called to account for declining to obey" (Annals 1: 203). Adams amplified the difference between blind obedience to church authority and preferable rhetorical conduct when defending the exercise of individual conscience. He objected to what appeared to be "a new measure of conduct" by the General Assembly that "would oblige Presbyteries to execute their orders, without taking any thing into consideration but the authority of the court" (Annals 1: 203). Adams specified the multiple arguments that ought to be considered, and used as a foil invoking institutional authority and threatening punishment:

whatever scruples [he and other presbyters] might have; whatever persuasions of mind they might entertain of the rule of duty, relating to their own personal actings; whatever consequences they might foresee to attend the part they acted;--all was to be sacrificed at once to this single principle, submission to authority,--a principle, therefore, which must be enforced by threatenings, censures, forfeitures, and all the terrible engines of power. But are these means of enlightening the mind [...] are these the arguments by which the ministers of Christ ought to ply one another? (Annals 1:203)

Adams advocated "enlightening the mind" by means of multiple arguments (e.g., considering the rule of duty, their own actions, and consequences) instead of stating in a "peremptory manner" the "single principle" of "submission to authority" supported by "terrible engines of power" such as threats and censures.

Adams described in detail the reasoning that served as grounds for refusing a General Assembly order to preside at the settlement of a minister objectionable to parishioners. For example, presbyters considered harmful consequences of "a violent settlement" (Annals 1: 205) of a minister objectionable to parishioners; they believed their participation in the settlement 
would lead to ministers losing their influence over parishioners, and parishioners would then follow separatists, "some of whom are well known to teach as wild and pernicious principles of government, as they do of religion" (Annals 1:206). Adams described "the light in which we have fairly examined our present conduct" and asserted that a defense of disobedience "ought never to be stated upon a slight ground" (Annals 1:208). Adams proffered the core grounds: disobeying an order of a superior court ought not to merit censure when disobeying it would lead to harmful consequences and when it is possible to appoint others to execute the order (Annals 1: 208). Thus Adams called for presenting and critically scrutinizing grounds for disobeying church authority.

The issue before the General Assembly in this case-whether to rebuke for disobedience only, or to suspend Adams and other presbyters for disobeying an order of the General Assembly and refusing to preside at Watson's settlement—was decided by a 200-11vote to rebuke only (Annals 1: 211-212). Adams and other presbyters were not forced to preside at Watson's settlement; instead, that task was performed by a committee appointed by the General Assembly (Annals 1: 212). The decision was a Popular party victory over future Moderates, including Robertson, who called for the General Assembly to impose the most severe sentence possible: suspension of disobedient clergy.

In sum, Adams advocated what would come to be called a Popular party position. Adams used the term "moderation" to advocate for a rhetorical procedure of considering multiple arguments about a particular case where the decision achieves legitimacy by withstanding critical scrutiny. He used as a foil peremptory decisions based on a single argument— submission to authority — and depending on threats of punishment for their legitimacy. 


\section{The Case of Gillespie}

\section{"Answers to the Reasons of Dissent"}

The second case Witherspoon mentioned as an example of the abuse of church authority that lead him to publish Ecclesiastical Characteristics featured Thomas Gillespie, a member of the clergy who also declined to be present at a settlement (Annals 1: 222-279, 2: 1-9; Collins 3334; Sher 52-55). In the course of arguing that clergy should not be censured for refusing to attend the settlement, Popular party members advocated rhetorical conduct featuring reasoning and argument, and used as a foil merely asserting and making authoritarian pronouncements. The case began in 1750 in the parish of Inverkeithing, when the local presbytery of Dunfermline refused to settle Andrew Richardson, a minister lawfully presented by the patron (Annals 1: 182183). In a November 1751 meeting of a General Assembly Commission, the issue "began to assume a serious aspect" (Annals 1:222). At that meeting the Commission ordered the presbytery to admit the minister in January, and in the case of disobedience, "the Commission will at their meeting in March next proceed against them to very high censure" (Annals 1: 227). The presbytery did not admit the minister so, when the Commission met in March 1752, the patron and others who supported the minister's settlement presented a petition calling for censure of the presbytery and for settlement of the minister (Annals 1: 228). However, the Commission "by a small majority" (Annals 1:230) voted to not censure the presbytery. Then the Commission, "without a vote, appointed the Synod of Fife, at their next ordinary meeting, to adjourn to Inverkeithing, in order to [sic] Mr Richardson's settlement there" (Annals 1:230) and report on the proceedings at the next Assembly in May 1752.

Moderates, including Blair, dissented from the decision to not censure; they favored censure for disobeying a General Assembly order and "craved leave to enter their dissent from 
this judgment, and to complain of it to the next Assembly" (Annals 1: 230). The Commission appointed others to prepare answers to the Moderates' reasons of dissent; Witherspoon may have been the primary composer of the answers (Collins 33; Sher 54). The Moderates' "Reasons of Dissent" has been described as "the Manifesto of the Moderate Party" (Annals 1: 231), and “Answers to the Reasons of Dissent" could be called "the Manifesto of the Popular Party, although there was never perhaps the same unity either of sentiment or action among them as among their opponents" (Annals 1: 242).

"Answers to the Reasons of Dissent" advocated a rhetorical process featuring multiple arguments and reasoning. "Answers” began by accusing Moderates of having "unhappily degenerated from the mild spirit, and cautious measures, of some of the wisest of our predecessors" and of producing, instead of reasons for dissent, "a paper wholly made up, either of loose and unguarded propositions; or of such general principles as nobody denies, quite misapplied in the present case" (Annals 1: 243). "Answers" then described the rhetorical process by which the Commission came to the decision to not censure the presbytery: it noted that when the presbytery was called to the bar "to give their reasons for not obeying the appointment of the Commission in November," then the commission, "[c]onsidering the whole affair, and particularly the foresaid defences," decided to inflict no censure (Annals 1: 244; emphasis in original). "Answers" bolstered the legitimacy of the decision by describing the process by which it was made as featuring multiple arguments, and contrasted that process with "hideous outcries" made against it by Moderates and "advanced without any shadow of proof” (Annals 1: 244; see also Annals 1: 248).

"Answers" argued that calls for blind obedience to "the supreme powers in any society" stripped clergy of their power to reason and reflect. If obedience to orders of superiors were 
outside the scope of critical scrutiny, "a machine [should] execute their sentences" (Annals 1: 246). "Answers" argued that unreflectively obeying orders of church authorities against the reflective conclusions of individual conscience will be indefensible at the final judgment: rational creatures of God [. . .] are answerable to him, their supreme judge, for all their own acts and deeds [...] Nor will it be a defence, or excuse, before his awful tribunal, that in doing an action which their consciences told them was contrary to his will, they willingly (or headlong, and without asking questions) walked after the commandment of any earthly superior whatsoever. (Annals $1: 246)$

"Answers" recommended rhetorical processes of decision-making by presenting even God, the "supreme judge," as open to hearing a defense of "acts and deeds." "Answers" advocated that commandments by earthly superiors ought to be critically scrutinized by "rational creatures of God," and used as a foil unreflectively acting as "a machine" and "without asking questions."

"Answers" described acting on individual conscience as exercising critical scrutiny by dint of "God's making us reasonable creatures" (1:253). Acting on individual conscience did not involve doing what appears good in an individual's own eyes while "darkened by irregular passions and appetites, without regard to the will of God" (Annals 1: 253). Instead it involved “seriously weighing the matter" (Annals 1:259) and "doing what, upon the most serious attention and consideration, appears to him good in the eyes of God and Christ" (Annals 1: 253), perhaps considering "obedience to the standing laws, on which the welfare of the whole depends" rather than only "decisions of the annual Assemblies in their judicative capacity" (Witherspoon, Serious 44). Thus “Answers," like Adams, called for critical scrutiny of orders by church authorities. 
"Answers" described the appeals process in terms of parties" power to argue before a higher court and used as a foil describing superior courts as exercising institutional, authoritative power over parties and asserting pompously rather than reasoning. "Answers" argued that the excellence of subordination of courts at different levels laid "not in the power of church-courts to distress their brethren, but in access which parties have, when they think themselves injured, to seek redress, by appeals to the superior courts" (e.g., presbyteries to synods, synods to the General Assembly) (Annals 1:255). "Answers" accused Moderates of offering no proof that failure to censure will produce harms, "but [instead], in their usual way, affirming it in a pompous manner" (Annals 1:257). Like Adams, "Answers" held that the legitimacy of decisions is based in procedures involving argument and reasoning, as opposed to enforcing decisions by institutional authority only.

In short, “Answers" advocated for a rhetorical process that involved making multiple arguments and exercising reason, and used as a foil mere assertions, "pompous" pronouncements, and calls for mindless obedience to superior institutional authority.

\section{Witherspoon's Ecclesiastical Characteristics}

Clash over patronage and rhetorical theory continued outside of the General Assembly in pamphlet form. Popular party member John Witherspoon's Ecclesiastical Characteristics, a biting satire of Moderates, ran to at least eight editions during the 1750s and 1760s (Miller, "Introduction" 49-50; Sher 58). Witherspoon was "provoked" (Annals 1: 242n.; Witherspoon, Serious 13) to publish it by one of the pamphlets defending the Moderate party's position and deposition (removal from the Church of Scotland) of Thomas Gillespie, one of the six ministers who refused to comply with the order to admit Andrew Richardson, the minister recommended 
by the patron in the parish of Inverkeithing. The decision to depose Gillespie was a result of what had been expected to be "a violent party struggle" (Annals 1:260) over the case when the General Assembly met in May 1752. The case "was discussed in every presbytery, and synod, and manse; and an unsuccessful effort was made to reinstate the victim" (Collins 34). Prior to the next General Assembly meeting in May 1753, pamphlets circulated, some defending the deposing of Gillespie and others calling for his reinstatement (Sher 55). In May 1753 the Assembly voted by a majority of three to not reinstate Gillespie (Annals 1: 278). Sher has credited the Moderate victory "largely to effective political management" (55).

Ten years after the first edition of Ecclesiastical Characteristics was published, Witherspoon explained that he wrote it because he felt "a deep concern for the declining interest of religion in the church of Scotland, mixed with some indignation at what appeared to me a strange abuse of church-authority in the years 1751-1752" (Serious 6). He described the pamphlet as "an attack upon the principles, manners, and political conduct of certain clergymen" (Serious 7) designed to serve as an exposé of the Moderate character (Serious 7-8, 9, 12, 32, 43). Witherspoon believed that if he "could exhibit them [Moderates] to the public in the same light in which they appeared to myself, they would make a pretty comical figure: and so it happened in fact" (Serious 20). Witherspoon's satirical pamphlet described rhetoric poor in both form and procedure, as absence of argument goes hand in hand with authoritarianism.

Witherspoon described appropriate rhetorical conduct as making multiple arguments based on relevant content knowledge: "[m]any attempts had been made to reason with them [Moderates], and clear appeals to the history and standing acts of the church" (Serious 20). But according to Witherspoon that material was not treated by Moderates as matter to reason upon and instead was "trodden under foot by the decisions of the annual assemblies, in their judicative 
capacity" (Serious 20-21). He blamed Moderates for substituting institutional coercive power for arguing and reasoning: "they at last became so confident of their own power, and so deaf to all reasoning on the subject, that they refused even to read what was written by those of different sentiments; and when they did read it, disdained to make any answer to it, or attempt to convince them any other way than by the unanswerable argument of deposition" (Serious 21). Thus Witherspoon advocated using appeals to content knowledge ("the history and standing acts of the church"), arguing, and reasoning, and used as a foil authoritarianism in the form of decisions enforced by threats.

Witherspoon defended his use of satire in a serious church matter (Landsman 35-36) by explaining that Moderates were not managing disagreement by arguing and debating even though they paid lip service to moderation. He described their use of the term "moderation" as "a fashionable or cant phrase among them; and yet they were running headlong into the most violent and tyrannical measures" (Serious 19). Although "[t]hey made great pretences [sic] to charity, and a large manner of thinking" (Serious 19), they considered "all who did not form the same opinions in religion and government with themselves, [to be] weak silly fools, except two or three knaves who had the direction of the rest. This, I do affirm, was not barely hinted, but openly and confidently asserted; so that I never knew greater bigots, in the proper and genuine sense of that word" (Serious 19-20). Thus Witherspoon suggested that Moderates were not living up to the qualities they said they valued: free inquiry and debate over bigotry, liberty over tyranny, and toleration over persecution.

Ecclesiastical Characteristics comprised a preface, introduction, thirteen "maxims" amplified for several pages each, and a conclusion (Collins 35-38; Sher 57-59) written in the voice of a Moderate. ${ }^{5}$ The maxims and discussions of each provide "a complete system of 
moderation, containing all the principles of it, and giving a distinct view of their mutual influence one upon another, as well as proving their reasonableness, and shewing [sic], by examples, how they ought to be put in practice" (16). The maxims to which Witherspoon devoted the most pages are most directly relevant to rhetorical theorizing: maxim 4 on preaching (rhetoric as performance), and maxim 10 on disputed settlements (rhetoric as systemic). Maxim 10 frames the following analysis because it most clearly shows and is representative of Popular party foiling of Moderate party rhetorical processes. Maxim 10 is:

Whenever we have got a settlement decided over the belly of perhaps the whole people in the parish, by a majority in the General Assembly, the victory should be improved, by appointing some of the orthodox opposers of the settlement to execute it, especially those of them that pretend to have a scruple of conscience at having an active hand in any such settlement. (52)

As the following analysis will illustrate, in discussing maxim 10 Witherspoon theorized poor rhetorical conduct by satirizing Moderates for managing disagreement with a single authoritarian argument, threats, and rhetorical "flourishes," featuring fashionable philosophical terms, to effectively coerce obedience and win majorities.

Witherspoon satirized Moderate party rhetorical procedures as authoritarian and coercive, but also as effective means for getting stubborn, dull Popular party members to do what Moderates wanted. For example, Witherspoon opined in the voice of a Moderate that "the best method of conviction, and, of all others, the most proper for a church-court, is that of authority, supported in its highest rigour by censures, which may be felt by men of the dullest capacities, as deposition and suspension from benefice as well as office" (58). After suggesting that for a time Protestants faulted Catholics for deploying institutional authority and threats but now Moderates 
do the same, Witherspoon described threats of censure as a "weapon" to drive "the beasts of burden" (Popular party members) who are such "dull and lifeless animals (as they are most of them past the vigour of youth) that no other argument can make any impression upon them" (5859). To show the "dulness and stupidity of these obstinate beings," he satirically adduced "the expence of rhetoric that has been thrown away upon them, to persuade them of a thing as clear as the sun, viz. that if they had any conscience they would depose themselves" (59). He asked readers to judge "how uncapable $[s i c]$ of persuasion one must be, to find difficulty in so plain a case, and therefore how necessary it is, that a more effectual method should be tried" (59). In short, Witherspoon criticized deployment of the "weapon" of institutional authority and threat of censure. He satirized the position that authority and threat are necessary when opponents are dull, stupid, and obstinate — when they cannot see without proof the truth of a self-evident maxim — and when they are too old for arguments to make an impression on them. He featured the goal of "effectual" persuasion, or getting one's own way: winning rather than playing the game well.

Witherspoon also satirized the rhetorical conduct of self-styled gentlemen serving as lay elders in the General Assembly and the young Moderate clergy who tried to imitate them. Witherspoon stated that "the laity who attend our judicatories" were beyond the reach of censure and "not much accustomed to solving cases of conscience" (59). Instead of reasoning about the details of cases, they use "the more gentleman-like method, for which Alexander the Great is so justly celebrated, viz. cutting the troublesome knot, which they would find tedious and difficult to unty [sic]" (59). The young clergy who "are imitators of the manners of gentlemen, may be supposed to act with the same spirit in public judgment" (59). He satirized Moderates' "great contempt" (60) for logic: "it is not to be expected, that such brisk and lively spirits, who always 
hated every thing that looked scholastic-like, can bear to be tied down to the strict methods of argumentation" (60). He satirized Moderate smugness about their being "masters in this method of conviction" but dismissing the methods of logic and argumentation because their "blood may easily be supposed too warm for any thing that is so slow, and at best so uncertain in its success" (60). Taking some lines from Samuel Butler's "Hudibras," Witherspoon sketched a gentlemanlike version of rhetoric - "frothy, unprofitable discourse in persons of the sacred character" (63) - that could be deployed rather than argument and reasoning: "they can give flourishes of rhetoric enough; nay, though of one of them in particular, I may literally say, '--- He cannot ope / His mouth, but out there flies a trope" (59). Witherspoon associated rhetorical "flourishes" with effective, coercive authority: "we are now the majority, and our power, as a late acquisition, is the more agreeable for being new, we must taste the sweets of authority, which can only be by compelling our inferiours to obey us" (60). Thus Witherspoon implied that rhetorical conduct preferable to froth, flourish, and coercion involved reaching and legitimizing decisions through a process of argument and reasoning.

Witherspoon also faulted Moderates for deploying a fashionable, easy-to-learn philosophical idiom - part of a "contemporary tendency toward intellectual superficiality" (Collins 28) - rather than content knowledge of religion. Witherspoon satirized the idiom of natural philosophy by including in Ecclesiastical Characteristics an "Athenian Creed" that almost certainly alluded to Kames" doctrine of necessity: "I myself am a little glorious piece of clock-work, a wheel within a wheel, or rather a pendulum in this grand machine, swinging hither and thither by the different impulses of fate and destiny" (43; see also $32,37,62)$. But the philosophical idiom that Witherspoon satirized with most bite was "the present fashionable scheme of moral philosophy" (51) authored by Shaftesbury and Hutcheson. He satirized 
Moderate use of the idiom for speaking of "virtue" rather than "religion" (31), and for holding that "virtue is founded upon instinct and affection, not upon reason" (68). Witherspoon mocked Moderate use of a philosophical idiom as a substitute for knowledge of scriptures, divinity, church history, and the like. For example, he wrote satirically as a Moderate that "In order to determine which side to choose in a disputed question, it requires no long discussions of reason, no critical inquiry into the truth of controverted facts, but only some knowledge of the characters of men, a study much more agreeable, as well as more common, than that of books" (68). Acquaintance with the moral philosophy of Shaftesbury and Hutcheson is "a shorter method of learning" (34) than "the critical study of the scriptures, [ . . ] reading large bodies of divinity, [ . . .] an acquaintance with church history, or the writings of these poor creatures, the Christian fathers" (40). Witherspoon satirized Moderate contempt for learning: "Much study is a great enemy to politeness in men" (39). But by "[s]cattering a few phrases in their sermons, as harmony, order, proportion, taste, sense of beauty, balance of the affections, etc." (41; see also 22), Moderates "are, in fact, thought to be very learned in their sermons by the vulgar, who, for that reason, hate him" ( 41 ; see also $22,27,28-29,48,50,61)$. Kidd has summarized Witherspoon's position on Moderates' use of a philosophical idiom: "Lacking genuine erudition, the Moderates deployed instead the fashionable cant and catch phrases of modern learning" (66). The anonymous author of Letter to the Author of the Ecclesiastick Characteristicks, writing in the vein of Witherspoon, connected fashionable talk to political machinations by extolling the "hopeful Youths [. . .] who, like so many noble Patriots of the Church, will, by Dint of Stratagem and Elocution, confound the Policy of our Adversaries, and despise them" (Moir 7-8; emphasis added). 
In short, Witherspoon portrayed Moderates as influencing by threats, insults, flourishes, and fashionable cant phrases that separated them from both opposing clerical peers and parishioners. As Miller has noted, "the Moderates did tend to resist public opinion and rely on the political support of the upper classes in a way that created considerable alienation within the Church" as "seen in the rising number of seceders" at the time ("Introduction" 13). Witherspoon implied that clergy ought to manage disagreement by making arguments based on substantive content knowledge of Scripture and ecclesiastical history.

\section{Conclusions}

This essay has added a plotline to histories of rhetoric that have analyzed belletristic rhetorics for their suitability for social and economic circumstances of the middling classes. I have recovered Popular party rhetorical theory by analyzing their metadiscourse about their own and opponents' rhetorical performances in the General Assembly of the Church of Scotland. Regardless of its accuracy, Popular party metadiscourse portrays Moderate party rhetorical conduct as a foil to their own. However, the Popular party account of base rhetoric aligns with Kamesian belletristic rhetorical theory. Analysis of Popular party rhetorical theory suggests that the forms and procedures comprising Kamesian belletristic theory—a single categorical argument based on a principle of human nature discovered by the new, fashionable mode of introspection performed by those who defined themselves as authorities in matters of taste; they

possessed just the right human nature generalizable to humanity—gained appeal in part as a way of accruing social and political power in the Church of Scotland and then Scottish universities. Popular party clergy attributed to Moderates the view that making multiple arguments based on relevant content knowledge was not an effective, efficient means for achieving power in the 
Church of Scotland; instead authoritarian, coercive, fashionable appeals enabled Moderates to curry favor and achieve majority votes.

By reconstructing the rhetorical theory of Popular party members, we may not need to do as much scholarly squinting to find usable, historical accounts of rhetoric as systemic. Popular party clergy advocated arguing and reasoning based on substantive knowledge as a method of arriving at and authorizing decisions. They described their rhetorical conduct as preferable to engaging in political decision-making processes in a peremptory manner, counting on threats to authorize a decision, and achieving majorities by behind-the-scenes machinations that involve currying favor with people in power.

${ }^{1}$ Rhetorical theorizing by the Popular party has not been analyzed, perhaps because it does not take the form of publications with the word "rhetoric" in the title; perhaps because a scholarly trend is to analyze rhetorical theories at this time in broader, cultural contexts and outside of elite institutions; or perhaps because the Popular party was on the losing side in Church politics. Even in North America, Blair's published lectures on rhetoric and belles lettres "overwhelmed" (Broaddus 40) those of Witherspoon.

${ }^{2}$ The institutional structure of the Church of Scotland had an "open and democratic character" (Sher 46). The General Assembly met for one week each May to deliberate and make church laws. A new Moderator of the General Assembly was nominated and elected each year, and the composition of the General Assembly changed annually. It comprised "several hundred parish ministers and lay elders from all parts of Scotland, most of whom had not attended the previous assembly and would not attend the next one" (Sher 46). Members of the General Assembly were nominated by ministers and lay elders in presbyteries, and there were "strict rotations used by most presbyteries to ensure an equitable distribution of assembly seats among the ministers in 
their jurisdictions" (Sher 46). Scotland was divided into provincial synods, which were divided into presbyteries, which were divided into kirk sessions. Presbyteries could prepare overtures to be debated in the General Assembly and made law. In addition, decisions of presbyteries could be appealed to synods, and decisions of synods to the General Assembly. Representations of positions were made to members of these bodies who debated and cast votes (Yates 15).

${ }^{3}$ One historian has recently described Moderate leader William Robertson's history of Scotland as "primarily an exercise in belles lettres, not in historical accuracy" and parts of Adam Smith's Wealth of Nations as "another fanciful if elegant exercise in belle lettres" (Macinnes 24, 27). 4 The case of Gillespie has been the focus of historians' accounts of the Moderate party (e.g., Collins 33-35). Sher covers the Adams case briefly (51-52) and the Gillespie case in more detail (52-55). Moderates were defeated in the case of Adams but not Gillespie. The main question in both cases was whether the General Assembly should censure members of presbyteries who refused to execute its orders to settle ministers who were objectionable to members of the presbyteries and their parishes.

${ }^{5}$ I quote from the "corrected and enlarged" fourth Glasgow edition, 1755. It differed from the first edition in that it included a preface and thirteenth maxim, both added in the second edition.

\section{Works cited}

Agnew, Lois. “The Civic Function of Taste: A Re-Assessment of Hugh Blair's Rhetorical Theory." Rhetoric Society Quarterly, vol. 28, no. 2, 1998, pp. 25-36. Agnew, Lois Peters. Outward Visible Propriety: Stoic Philosophy and Eighteenth-Century British Rhetorics. University of South Carolina Press, 2008. 
Annals of the General Assembly of the Church of Scotland, from the Final Secession in 1739, to the Origin of the Relief in 1752. Vol. 1. Edinburgh, 1838.

Annals of the General Assembly of the Church of Scotland, from the Origin of the Relief in 1752 to the Rejection of the Overture on Schism in 1766. Vol. 2. Edinburgh, 1840.

Bator, Paul G. "The Unpublished Rhetoric Lectures of Robert Watson, Professor of Logic, Rhetoric, and Metaphysics at the University of St. Andrews, 1756-1778." Rhetorica, vol. 12, no. 1, 1994, pp. 67-113.

Blair, Hugh. “Observations upon a Pamphlet (1755),” edited by Sean Patrick O’Rourke. Advances in the History of Rhetoric, vol. 14, no. 2, 2011, pp. 220-238.

Bonar, John. An Analysis of the Moral and Religious Sentiments contained in the Writings of Sopho, and David Hume, Esq. Edinburgh, 1755.

Broaddus, Dottie. "Authoring Elitism: Francis Hutcheson and Hugh Blair in Scotland and America." Rhetoric Society Quarterly, vol. 24, no. 3/4, 1994, pp. 39-52.

Burke, Kenneth. A Grammar of Motives. University of California Press, 1969.

Collins, Varnum Lansing. President Witherspoon. Princeton University Press, 1925.

Conley, Thomas M. Rhetoric in the European Tradition. University of Chicago Press, 1990.

Craig, Robert T. "How we Talk about Talk: Communication Theory in the Public Interest." Journal of Communication, vol. 55, no. 5, 2005, pp. 659-667.

Donovan, Robert Kent. "The Popular Party of the Church of Scotland and the American Revolution." Scotland and America in the Age of Enlightenment, edited by Richard B. Sher and Jeffrey R. Smitten. Princeton University Press, 1990. 81-99.

Ferreira-Buckley, Linda, and S. Michael Halloran. “Editors' Introduction.” Lectures on Rhetoric and Belles Lettres, by Hugh Blair. Southern Illinois University Press, 2005. xv-liv. 
Halloran, S. Michael. “John Witherspoon on Eloquence.” Rhetoric Society Quarterly, vol. 17, no. 2, 1987, pp. 177-92.

Harrington, Dana. “Developing Democratic Dispositions. Eighteenth-Century Public Debating Societies and the Generative Capacity of Decorum." Rhetoric Society Quarterly, vol. 45, no. 4, 2015, pp. 324-345.

Hauser, Gerard A. Vernacular Voices: The Rhetoric of Publics and Public Spheres. University of South Carolina Press, 1999.

Howell, Wilbur Samuel. Eighteenth-Century British Logic and Rhetoric. Princeton University Press, 1971.

Kames, Lord. Elements of Criticism. 2 vols. Edinburgh, 1765.

Kidd, Colin. "Enlightenment and Anti-Enlightenment in Eighteenth-Century Scotland: an Ayrshire-Renfrewshire Microclimate." The Enlightenment in Scotland: National and International Perspectives, edited by Jean-François Dunyach and Ann Thomson. Voltaire Foundation, 2015. 59-84.

Landsman, Ned C. "Witherspoon and the Problem of Provincial Identity in Scottish Evangelical Culture." Scotland and America in the Age of Enlightenment, edited by Richard B. Sher and Jeffrey R. Smitten. Princeton University Press, 1990. 29-45.

Longaker, Mark Garrett. “The Political Economy of Rhetorical Style: Hugh Blair's Response to the Civic-Commercial Dilemma.” Quarterly Journal of Speech, vol. 94, no. 2, 2008, pp. 179199.

---. Rhetorical Style and Bourgeois Virtue: Capitalism and Civil Society in the British Enlightenment. Pennsylvania State University Press, 2015. 
Macinnes, Allan I. "Applied Enlightenment: Its Scottish Limitations in the Eighteenth Century." The Enlightenment in Scotland: National and International Perspectives, edited by JeanFrançois Dunyach and Ann Thomson. Voltaire Foundation, 2015. 21-58.

Manolescu, Beth Innocenti. "Motives for Practicing Shakespeare Criticism as a Rational Science." Advances in the History of Rhetoric: The First Six Years, edited by Richard Leo Enos and David E. Beard. Parlor Press, 2007. 296-307.

---. "Traditions of Rhetoric, Criticism, and Argument in Lord Kames's Elements of Criticism." Rhetoric Review, vol. 22, no. 3, 2003, pp. 225-42.

McKenna, Stephen J. Adam Smith: The Rhetoric of Propriety. State University of New York Press, 2006.

McKeon, Richard. "Rhetoric in the Middle Ages." Speculum, vol. 27, no. 1, 1942, pp. 1-32.

Miller, Thomas. "Introduction.” The Selected Writings of John Witherspoon, edited by Thomas Miller. Southern Illinois University Press, 1990. 1-56.

Miller, Thomas P. The Formation of College English: Rhetoric and Belles Lettres in the British Cultural Provinces. University of Pittsburgh Press, 1997.

---. "John Witherspoon and Scottish Rhetoric and Moral Philosophy in America." Rhetorica, vol. 10, no. 4, 1992, pp. 381-403.

---. "Witherspoon, Blair and the Rhetoric of Civic Humanism." Scotland and America in the Age of Enlightenment, edited by Richard B. Sher and Jeffrey R. Smitten. Princeton University Press, 1990. 100-114.

Moir, Andrew. A Letter to the Author of the Ecclesiastick Characteristicks. Glasgow, 1754. Potkay, Adam. The Fate of Eloquence in the Age of Hume. Cornell University Press, 1994. 
Rhodes, Neil. "From Rhetoric to Criticism." The Scottish Invention of English Literature, edited by Robert Crawford. Cambridge University Press, 1998. 22-36.

Richards, I. A. The Philosophy of Rhetoric. Oxford University Press, 1936.

Ross, Ian Simpson. Lord Kames and the Scotland of His Day. Clarendon Press, 1972.

Scott, J. Blake. “John Witherspoon's Normalizing Pedagogy of Ethos.” Rhetoric Review, vol. 16, no. 1,1997 , pp. 58-75.

Sher, Richard B. Church and University in the Scottish Enlightenment: The Moderate Literati of Edinburgh. Princeton University Press, 1985.

Tracy, Karen. Challenges of Ordinary Democracy: A Case Study in Deliberation and Dissent. Pennsylvania State University Press, 2010.

Walzer, Arthur E. "Blair's Ideal Orator: Civic Rhetoric and Christian Politeness in Lectures 2534.” Rhetorica, vol. 25 , no. 3, 2007, pp. 269-295.

---. George Campbell: Rhetoric in the Age of Enlightenment. State University of New York Press, 2003.

Wanzer-Serrano, Darrel. The New York Young Lords and the Struggle for Liberation. Temple University Press, 2015.

Witherspoon, John. Ecclesiastical Characteristics: or, the Arcana of Church Policy. $4^{\text {th }}$ ed. Glasgow, 1755.

---. A Serious Apology for the Ecclesiastical Characteristics. Edinburgh, 1763.

Yates, Nigel. Eighteenth-Century Britain, 1714-1815: Religion, Politics, and Society in Britain. Routledge, 2014. 